\title{
Rural Electrification through Decentralized Concentrating Solar Power: Technological and Socio-Economic Aspects
}

\author{
Sylvain Quoilin ${ }^{1}$, Matthew Orosz ${ }^{2}$ \\ ${ }^{1}$ Energy Systems Research Unit \\ Université de Liège, Belgium \\ e-mail: squoilin@ulg.ac.be \\ ${ }^{2}$ Parsons Laboratory \\ Massachusetts Institute of Technology (MIT), USA
}

\begin{abstract}
Cite as: Quoilin, S., Orosz, M., Rural Electrification through Decentralized Concentrating Solar Power: Technological and Socio-Economic Aspects, J. sustain. dev. energy water environ. syst., 1(3), pp 199-212, 2013, DOI: http://dx.doi.org/10.13044/j.sdewes.2013.01.0015
\end{abstract}

\begin{abstract}
This paper presents the development of small-scale solar Organic Rankine Cycles for rural electrification in remote areas of Lesotho. It is subdivided in two parts. The first part deals with the success conditions of decentralized rural electrification projects. Through a literature survey, relevant guiding principles and recommendations are formulated. The second part of the paper describes the proposed system, which is designed in agreement with the formulated recommendations. A framework for benchmarking the performance and cost of various micro-utility platforms and rural electrification distribution models is proposed.
\end{abstract}

\section{KEYWORDS}

Rural electrification, Concentrating Solar Power, CSP, Organic Rankine Cycle, ORC, Off-grid, Development

\section{INTRODUCTION}

Energy access is a central preoccupation in the field of international development. A decade following the establishment of the Millennium Development Goals (MDGs), a significant fraction (over 20\%) of the world population continues to lack access to modern forms of energy such as electricity, LPG or renewable sources of energy [1]. Thermal energy demand is mainly met by traditional fuels (wood, dung, etc.), that are inefficient when converted to their final use and can cause negative externalities, such as e.g., health problems and environmental degradation [2].

The link between social indicators and energy consumption is significant for the majority of the countries in the world. Increased energy access can improve education, health or environmental conditions in developing countries, where the greatest effects on well-being (measured via the human development index) are being realized at the lowest per capita energy consumption rates [3].

Energy access includes electricity access in urban, peri-urban and rural areas, in other words a disparate geography that may encompass a wide range of production modes. The specific benefits of electricity are commonly understood to include, for example, an increase in the standard of living, improved education through e.g. lighting, or decreased time spent on domestic tasks such as wood collection. It cannot, however, be concluded that access to electricity automatically induces local production activity or economic growth [4]. Energy access appears to be a necessary but not sufficient condition to drive development. 
To provide electricity to remote areas of developing countries, decentralized power generation is often a more effective option than centralized power generation plants [5]. Decentralized power generation can be provided through a number of technologies such as diesel generators, solar photovoltaic (PV) systems, micro-hydraulic systems or biomass combustion. Each technology features inherent advantages and drawbacks, e.g. diesel engines have a high availability but are a source of atmospheric pollution and require expensive fuel; PV systems present a lower carbon footprint but necessitate high investment costs and rely on expensive and unreliable battery storage to overcome intermittency, and so forth.

In this work, an alternative technology is proposed, consisting in the coupling between a low-cost solar thermal concentrator and an Organic Rankine Cycle engine. The aim of the technology is to integrate within a distributed generation framework to provide rural areas of developing countries with a micro-grid platform that can be manufactured and assembled locally (unlike PV collectors) and can replace or supplement Diesel generators in off grid areas, by generating clean power at a lower levelized cost.

The first part of the paper deals with the success conditions of decentralized rural electrification projects. Through a literature survey, different guiding principles and recommendations are formulated. The second part of the paper describes the proposed system, and the design trade-offs that are considered in order to agree with the formulated guidelines.

\section{SUCCES FACTORS OF RURAL ELECTRIFICATION PROJECTS}

The history of development projects, in particular for rural electrification, has included high failure rates, often attributed to planning omissions where local institutions, the socio-economic environment or the hierarchical links between the different local actors were not taken into account [6].

This section aims at establishing success factors through a review of rural electrification projects, by reviewing examples of successes and failures where underlying factors were identified and classified. The proposed analysis is transversal: different types of criteria (economic, technical, social) are considered and analysed. Criteria related to the institutional arrangements of the project, while important, are outside the scope of this study. According to Barnes [7] reporting eight success stories of rural electrification, the institutional model is not a critical element: he argues that these models are highly variable depending, for example, on the geographic configuration or socio-economic environment of the project and that it is preferable to respect relevant guiding principles within a project framework. The author acknowledges that institutional factors play a role in generating project objectives, funding implementation and evaluating and leveraging outcomes, and these will be identified with reference to the proposed system of the second half of the paper. For the purposes of this study however, we will follow Barnes in focusing the analysis within a project framework to identify a standard approach within the development community as applied to energy projects. This approach may be classified according to distinct principles, as follows:

\section{Participation of the target population}

Numerous studies have shown that local participation to the electrification project is a sine qua non condition to their success $[8,9,10]$. Local communities are presumed to be more aware of their particular needs and situation, and of the issues linked to the project [2]. In any case, it seems obvious that a local demand for the product (in this case: electricity) should be expressed before proceeding with any intervention. 
According to Cernea [10], many development projects have failed despite local enquiries and the inclusion of the local population in the project, possibly due to considering the local population as monolithic without distinguishing between subgroups. Cernea proposes that it is necessary to determine a "unit of social organization" able to carry out the project, and to include it in the decision process, including planning and execution of the project. In the absence of such a social unit, it may be possible within the context of an intervention to create a local association with ownership of the project and involved key decisions. This option has been tested successfully by Zilles [8] in the case of a PV electrification project in two rural communities in Mexico.

The main criteria in this respect are therefore the demand for the product, the identification of a proper unit of social organization and its inclusion in the decision and planning processes.

\section{Technology adoption}

Technology development and dissemination are usually differentiated and sequential. This typically involves the installation of a demonstration plant in the community (demonstration phase), followed by a diffusion phase. A demonstration/diffusion approach may yield good results in certain projects, e.g. in Mexico with the installation of 42,000 PV systems [8]. The demonstration/diffusion model relies on the intrinsic quality of the product, i.e. "if it is good/useful, adoption is inevitable". Salient examples of this principle in practice might include internal combustion engines and wireless telephony, both of which are widelydistributed in the developing world. Akrich [11] showed through selected examples that this principle is not always true, and that characteristics such as the evolutivity of the system are relevant (i.e. the technology should be designed in such a way that it can be taken over by the local population: it should not be presented as a "black box" but as a system that can be modified, adapted, tuned with regards to the local needs). In the case of early cell phone adoption it is not clear that this condition was ever met, although the advent of more advanced mobile device platforms has recently provided scope for considerable user-generated applications.

\section{3. "Appropriate" technology}

Some authors aspire for alternative technologies, distinct from mainstream technologies, but more efficient and adaptable yet. Schumacher [13] calls such a technology an "Intermediate technology", i.e. a more cost effective technology inviting the creativity of its users to adapt and to improve it. This technology would presumably be engineered to be more labour-intensive than capital-intensive, better adapted to the situation of developing countries, where labour tends to be in surplus relative to capital. The relative merits of such an approach, however, have yet to be rigorously quantified in the context of economic development.

The experience of photovoltaic installations in developing countries clearly shows that reliability is one of the key factors for technology adoption. Frequent failures, even of small and widely available components, cause rapid dissatisfaction among the users, who generally refuse to reimburse the fees when the system was sold on credit [8]. In the 1970 's, a high rate of malfunction or failure was noted on photovoltaic installations, mainly due to a lack of technical maturity. While failures are normal to the process of improving technology, technical immaturity can be a cause of rejection of the technology by the local communities. A distinction should therefore be established between experimental units and large scale diffusion units. 
In the approach outlined above, appropriate technology possesses certain key-characteristics: effectiveness (meeting the demand) and reliability (low failure rate, vetted and mature technology) with some preference for simplicity (ease of use and understandability) and adaptability (ability to modify the device according to one's needs).

\section{Cost}

The majority of scientific publications on rural electrification focus on the comparative cost when selecting the most appropriate technology. Many authors consider economic payback as a non-negotiable prerequisite $[14,15]$. Others suggest a preselection of candidate technologies based on environmental or socio-economic aspects and then the use the cost criterion to select the remaining technologies post-hoc ${ }^{1}$ [16]. Technology selection in developing countries, however, may not be purely rational or based solely on economic return.

One prominent example is the generalized use of diesel generators to meet off-grid power demand. According to several authors [14, 18, 19], the levelized cost of PV Solar Home Systems (SHS) for individual use is lower than that of diesel generators. The key factor to explaining the selection of diesel generator is the investment cost: access to credit is indeed often limited for rural communities of developing countries [2, 16, 20], and the initial cost of PV systems is prohibitive for local users who prefer a pay-as-you-go model for fuel expenses.

Finally, some authors note that the externalities, defined as "costs that are not reflected in the cost of electricity", such as the costs linked to environmental impact of power generation [21] should be internalized when selecting energy generation technology. According to Zomers [20], decentralized technologies would become much more competitive if external costs were taken into account using, e.g. a life cycle cost assessment (discussed below).

\section{Technology transfer and maintenance}

Maintenance is a critical issue for decentralized power equipment: local technicians must be able to be able to fix or replace failed components. According to Martinot et al. [9], international aid for development has typically focused on providing the capital costs for decentralized systems, with a low fraction of aid dedicated to recurrent costs such as maintenance, and less than $10 \%$ spent on technical or managerial training. The lack of proper maintenance is one of the major causes of system failure, along with a misuse of the device [20]. Several barriers to the necessary technology transfer for system maintenance can be identified:

- A lack of access to components and materials [22]: this includes the absence of local manufacture or a limited access to international supply chains.

- A lack of industrial infrastructure, requiring costly and time-consuming transport of spares or repaired parts between the point of use and distant industrial centres [23].

\footnotetext{
${ }^{1}$ When calculating the cost of a given system, it is important to consider the system on its whole lifetime. The "Levelized Electricity Cost" (LEC) constitutes a good criterion for the comparison:

$$
\mathrm{LEC}=\frac{\mathrm{I}_{0}+\sum_{\mathrm{i}=1}^{\mathrm{n}} \frac{\mathrm{M}_{\mathrm{i}}+\mathrm{Fuel}_{\mathrm{i}}}{(1+\mathrm{t})^{\mathrm{i}}}}{\sum_{\mathrm{i}=1}^{\mathrm{n}} \frac{\mathrm{E}_{\mathrm{t}}}{(1+\mathrm{t})^{\mathrm{i}}}}
$$

with $L E C$ being the present $\mathrm{kWh}$ cost (USD/kWh), $I_{0}$ the investment cost (USD), $M_{i}$ the maintenance cost (USD), Fuel $_{i}$ the fuel cost (USD), $E_{i}$ the total yearly power generation (kWh), $t$ the actualisation rate (\%) and $n$ the system lifetime (years).
} 
- A dependence on imported components, with implications for cost, availability, customs and clearance delays, and local assimilation of the technology's core concepts [24].

- A lack of competent technicians and engineers with the knowledge and experience to undertake a maintenance program.

Rural electrification projects may therefore benefit from associated training programs, whose aim is to build capacity of local technicians and managers. The access to replacement components or materials being often problematic, it is important to privilege local components and manufacturing processes. In the case where no engineering infrastructure is present, it may be advantageous to create it, in the form of local workshops with appropriate equipment and tools. These workshops should moreover be designed in such a way that they can diversify their activities and become a source of local productive activity.

\section{Decentralization}

Historically, rural electrification has largely been conducted through centralized power generation and the extension of the electric grid [9]. Technological advances in decentralized power generation however, have made these technologies more competitive and continue to shift the calculus towards increased deployment. The spectrum of centralization to decentralization can be distinguished in three levels:

- Centralized power generation, with a reticulated electrical network serving a (usually heavily populated) geographic area.

- Mini or micro-grid: a grid serving the needs of a community or defined, co-located loads.

- Decentralized power generation: an individual unit covering the need of one household or load.

The two last levels may involve the use of local storage capacity (batteries). Typical systems include Solar Home Systems (PV), diesel generators, micro-hydraulic, or biomass gasification. Decentralized systems are a source of local employment, are more flexible in their operating modes, and provide a degree of autonomy from utility service (which may be unreliable in some areas).

The main criterion governing the choice of a decentralized solution is the relative cost of the technology compared to a centralized technology. This cost is a function of the geographic scenario (the cost function of extension is proportional to distance and increases with geographic obstacles) and the consumption density. The latter can be expressed as the number of connectable customers (weighted by estimated demand) per kilometre of grid extension. Whether or not cross-subsidy is contemplated, since the Levelized Electricity Cost (LEC) of grid electricity decreases with a higher consumption density while that of a decentralized system is more or less constant, from a capital investment perspective a break-even point exists where a lower consumption density favours the decentralized solution. Chakrabarti [19] calculated this break-even point for India and reached a distance of $16 \mathrm{~km}$, below which grid extension is more interesting than a PV system. A related analysis was performed by Chaurey [15] where the calculated break-even point between a PV mini-grid and PV Solar Home Systems was 200 households.

\section{Environmental impact}

In the energy field, environmental impacts are mainly related to the emission of pollutants, the effects of which can be toxic (microparticles, $\mathrm{CO}$, etc.), climate forcing $\left(\mathrm{CO}_{2}, \mathrm{~N}_{2} \mathrm{O}\right.$, methane, etc.) or potentially ozone depleting ( $\mathrm{CFC}, \mathrm{HCFC}, \mathrm{N}_{2} \mathrm{O}$, etc.). 
When assessing impacts, it is important not only to consider the emissions during the operational lifetime of the studied technology, but also to take into account the emissions arising from its construction to its disposal or recycling. Tools such as The Life Cycle Assessment (LCA) can be applied for such an analysis: in one study, PV systems were found to have a carbon footprint comprised between 98 and $167 \mathrm{gCO}_{2} / \mathrm{kWh}$ (depending on PV cell type and manufacturing process), while diesel combustion amounts to a minimum value of $772 \mathrm{gCO}_{2} / \mathrm{kWh}$ for a high efficiency generator. Meanwhile, $\mathrm{SO}_{2}$ and $\mathrm{NO}_{2}$ emissions are $0.2-0.34$ and $0.18-0.3 \mathrm{~g} / \mathrm{kWh}$ respectively for $\mathrm{PV}$ and 1.55 and 12.3 $\mathrm{g} / \mathrm{kWh}$ respectively for the diesel technology [20].

\section{Energy needs and demand}

It is difficult to establish the energy needs for a given population, especially as these are trending upwards for most segments of society. Prediction would normally be modelled on inventories of electrical devices, their power draw and duration of use, or by extrapolating load curve data measured in representative or aspirational population with existing service. In terms of gross energy consumption, per capita basic needs have been estimated at as low as $0.5 \mathrm{kWh}$ /day [25]. This estimation is performed by assuming minimum values for a number of indicators such as life expectancy, daily food consumption or living area and evaluating the minimum energy necessary to achieve these indicators.

It is however important to make a distinction between basic needs, perceived needs, and actual demand which is likely to be some combination of the two overlaid with economic factors (e.g. ability to pay, availability of subsidy). Some research has shown that non-basic needs can be prioritized over basic needs, such as a preference for television rather than e.g. lights for studying or a well pump for drinking water or irrigation [4].

The evaluation of energy demand can be performed via local inquiries (formal/informal, targeted/generalized, etc.) depending on the situation of the studied area. These inquiries should be carried out with care, with an awareness of their limitations and the anticipation that demand will evolve during a project [11].

\section{Technology deployment strategies}

One of the major obstacles to the deployment of decentralized renewables is the high initial cost. Therefore, project finance strategies are required in order to introduce the technology to the market and facilitate its deployment.

The extent to which the market should drive technology choice is subject to debate: on the one hand, prices should reflect the cost of the system in order to avoid market distortion and the promotion of poorly adapted technologies [2]. On the other hand, access to credit is generally limited and the payback period for decentralized generation infrastructure may discourage external investors or lenders. Moreover, political mandates exist to combat extreme poverty, which includes access to electricity [20].

Microcredit has been used at the household level to finance the initial purchase cost of systems, as described in a number of pilot projects in Asia, Africa and South America $[2,26]$. It should however be noted the number of systems sold at credit is very low compared to the number of systems sold for cash [9]. Other approaches can include a fee-for-service system (lease of a SHS system), or complete donation (in which case the maintenance costs are covered by the user). Niewenhout et al. [12] analysed and compared, through case studies, these different deployment strategies. They concluded that no strategy is optimal, each of them showing advantages and drawbacks. It was found, however, that donation represents the clearest case of market distortion, and the 
beneficiaries may not feel responsible for the offered unit or allocate resources towards maintenance.

\section{Subsidies}

Subsidies are motivated by different factors, such as the interest in promoting one technology (generally renewable) over another, the necessity to tackle extreme poverty, the promotion of "nascent industry" or reducing the initial cost barriers. As noted above, these subsidies can lead to market distortions or other deleterious effects, such as inefficient use of energy, or excessive benefit for some segment of the targeted population at the expense of other segments. These subsidies, when necessary to achieve a policy aim, should be limited in time (the time necessary for the introduction of the technology and the accompanying effects of scale) and targeted with respect to needs and outcomes.

\section{Summary}

A literature review has identified a general consensus regarding many of the success factors of rural electrification projects. This standard approach employs guiding principles that, when applied to specific energy projects, should, in theory, increase the probability of successful project outcomes (although this hypothesis should be subjected to empirical validation). The standard approach and selected guidelines and criteria are summarized in Table 1.

Table 1. Guiding principles and selected criteria

\begin{tabular}{|c|c|}
\hline Guiding principle & Selected criteria \\
\hline Participation of the beneficiaries & $\begin{array}{l}\text { Local demand, unit of social organization, inclusion } \\
\text { in the decision processes }\end{array}$ \\
\hline Technology adoption & Demonstration, adaptability \\
\hline Appropriate technology & $\begin{array}{l}\text { Reliability, technical maturity, simplicity, } \\
\text { adaptability }\end{array}$ \\
\hline Cost & $\begin{array}{l}\text { Comparative cost, capital and recurring costs, } \\
\text { externalities }\end{array}$ \\
\hline Technology transfer and maintenance & $\begin{array}{l}\text { Training, local components and materials, upstream } \\
\text { infrastructure, local productive activity }\end{array}$ \\
\hline Decentralization & $\begin{array}{l}\text { Relative cost, geographic configuration, } \\
\text { consumption density }\end{array}$ \\
\hline Environmental impact & Pollutants, life cycle analysis \\
\hline Needs and demand & Local inquiries, awareness of their limitations \\
\hline Technology deployment & Access to credit and microcredit, non-gratuity \\
\hline Subsidies & Time limitation, targeted subsidies \\
\hline
\end{tabular}

\section{THE PROPOSED SOLAR ORC SYSTEM}

Researchers at MIT and University of Liège have collaborated with the non-governmental organization STG International for the purpose of developing and implementing a small scale solar thermal technology utilizing medium temperature collectors and an ORC. A first unit was installed by STG in 2007, and is shown in Fig. 1.

The project goal is to develop mini-grid infrastructure appropriate to rural areas of developing countries, with Lesotho as a case study, in accordance with best practices such as formulated above. An institutional framework is also proposed, whereby a novel locally produced solar technology may be integrated with traditional micro-grid technologies to 
establish micro-utilities anchored at rural health and educational institutions. In the proposed framework, a local enterprise is capacitated to produce, own, operate and maintain the micro-utility infrastructure, and obtains project finance from lenders via a negotiated power purchase agreement (PPA) with institutional (government ministerial) customers. These arrangements serve to build local engineering capacity while importantly incentivizing the maintenance of the infrastructure. The institutional arrangements of the proposed micro-utility approach are illustrated in Fig. 2. As with other distribution approaches, the micro-utility and power purchase agreement model should be subject to empirical validation, which is an ongoing objective of STG International.

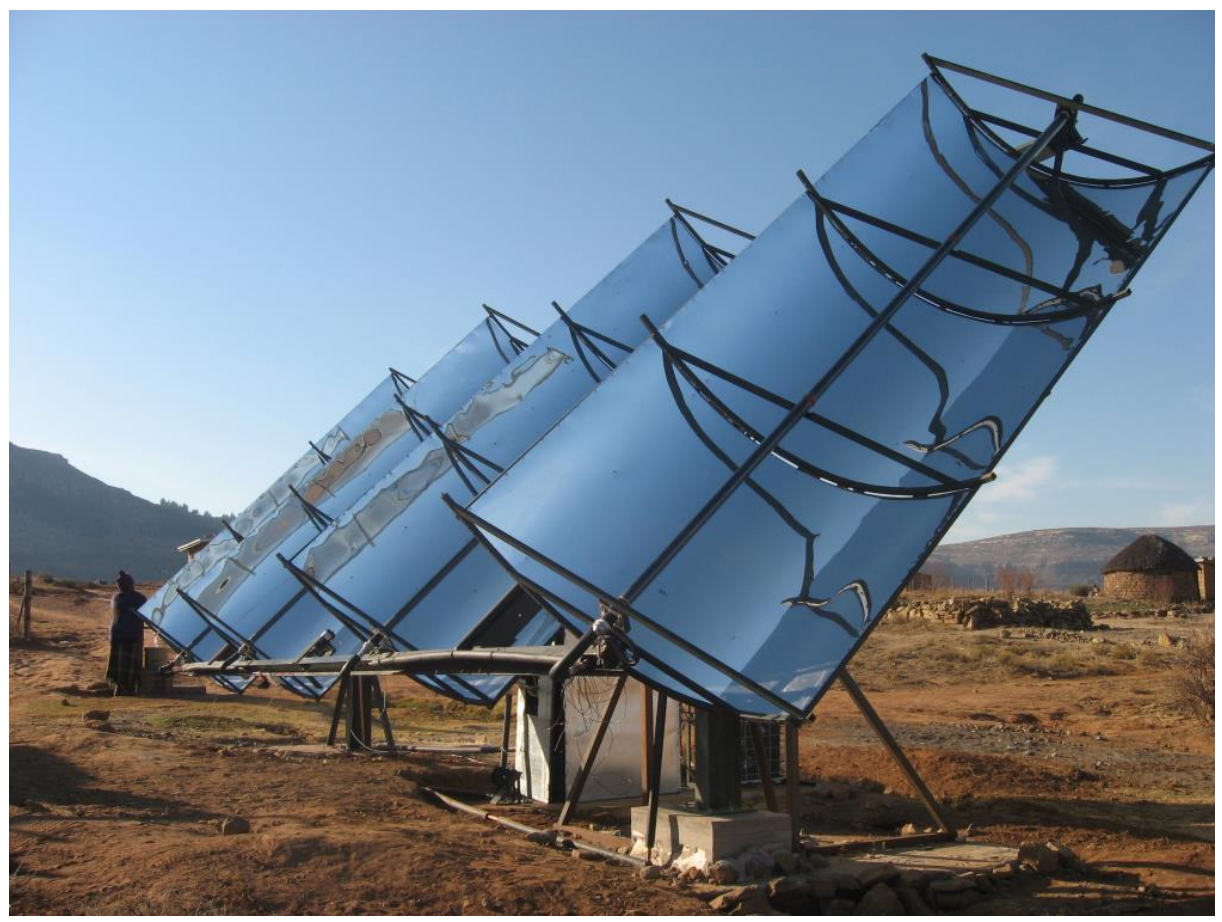

Figure 1. First solar ORC prototype installed by STG in Lesotho

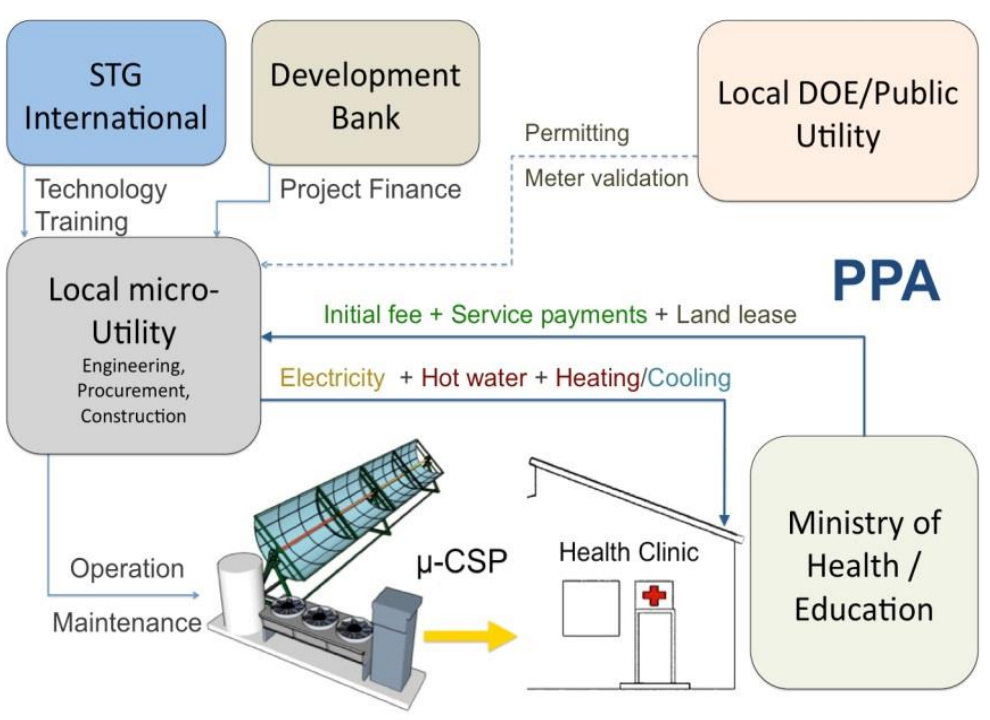

Figure 2. Institutional arrangements for distribution of energy services in rural areas via market mechanisms 
At the core of the proposed technology is a solar thermal power plant consisting of a field of parabolic solar concentrating collectors and a vapour expansion power block for generating electricity: solar radiation is concentrated towards a linear absorber at the focus point of the parabola, where a heat transfer fluid (HTF) is heated up. This HTF is driven to a storage tank accumulating heat in order to keep the system running in case of a short interruption in solar irradiation. HTF is then used to evaporate the organic fluid of the ORC cycle. The latter is driven to an expansion unit where useful work is produced. It is then condensed in the air condenser and pumped back to the evaporator. A recuperator is added between the pump outlet and the expander outlet in order to preheat the liquid before the evaporator, which increases the cycle efficiency. Thermal energy outputs (cogeneration) are also available from the thermal storage tank, which is a relatively more cost effective mechanism for energy storage than chemical batteries.

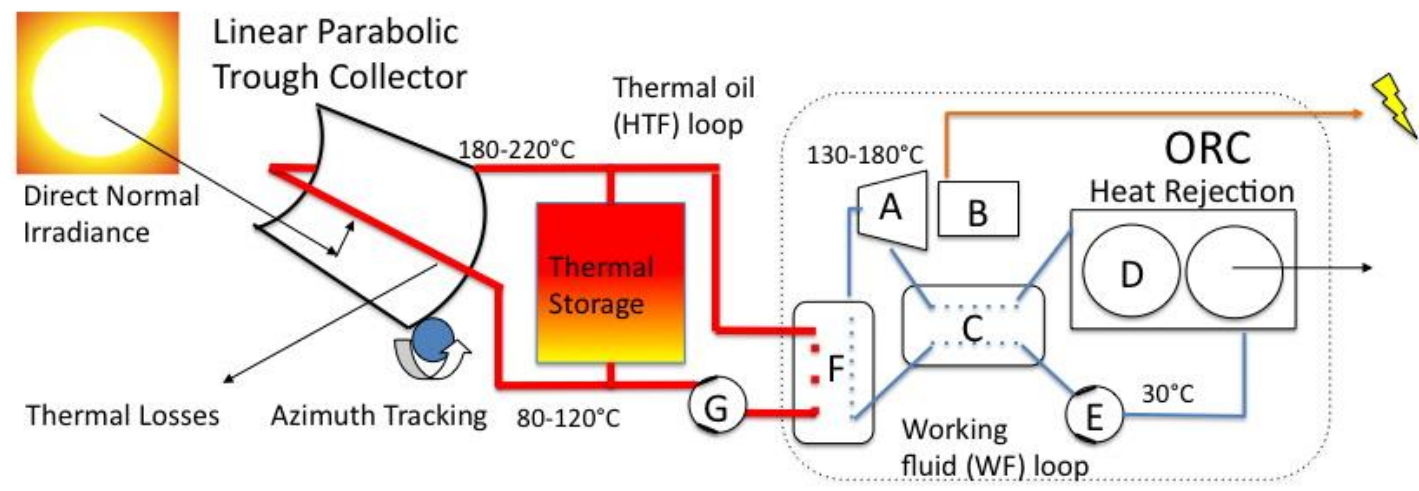

Figure 3. Conceptual scheme of the solar ORC with components listed as follows A:expander, B: generator, C: recuperator, D: air condenser, E: working fluid pump, F: evaporator, G: HTF pump

Because no thermal power blocks are currently manufactured in the kilowatt range a small-scale ORC has to be designed for this application. The design is based on modified commercially available components e.g. Heating Ventilation and Air Conditioning (HVAC) scroll compressors (for the expander), and industrial pumps and heat exchangers. At present, no volumetric expander is available on the market. In order to reduce the cost of a practicable system, the expander is obtained by adapting an off-the-shelf hermetic scroll compressor to run in reverse, as proposed and successfully tested by [27]. Scroll machines exhibit the advantage of being widely available, reliable and comprise a limited number of moving parts. The proposed technology thus presents the advantage of utilizing off-the-shelf components that are available locally through, e.g. global industrial component supply chains. These components include scroll compressors, heat exchangers, pumps and working fluids sourced from HVAC applications; industrial motors and reflective aluminium sheeting; standard steel structural and pipe sections; and standard microcontroller and power electronics. This constitutes an important difference with the PV systems where the major part of the components must be imported.

The main characteristics of a micro-utility sized for rural service providers are the following:

- Target net output power: $3 \mathrm{kWe}$

- Collector field: $75 \mathrm{~m}^{2}$ single-axis parabolic trough, using Miro aluminium reflectors and a Heat Collection Element (HCE) with selective coating and air-filled annulus between absorber pipe and glazing.

- ORC: two stage expansion of R245fa using modified commercial HVAC compressors, brazed plate heat exchangers for high pressure heat transfer, and commercial HVAC tubes-and-fins air condenser for heat rejection. 
- Heat transfer fluid (HTF): Propylene glycol with thermal buffering in a thermal storage tank with a $2 \mathrm{~m}^{3}$ packed bed of $19 \mathrm{~mm}$ quartzite aggregate

Table 2. Approximate cost of the main components

\begin{tabular}{|c|c|c|c|c|}
\hline Component & Description & $\begin{array}{l}\text { Industry } \\
\text { Supplier }\end{array}$ & Notes & $\begin{array}{l}\text { Approximate Cost } \\
\text { Data* }\end{array}$ \\
\hline 1. Glazing & Duran 50 & Schott Solar & $\begin{array}{l}\text { Borosilicate } 1.25 \mathrm{~m} \mathrm{~L} 84 \mathrm{~mm} 5 \\
\text { mm Thickness }\end{array}$ & $65 \mathrm{USD} / \mathrm{pc}$ \\
\hline 2. Reflector & Miro-4 & Alanod & $\begin{array}{l}1.25 \mathrm{~m} \mathrm{~W} 0.4 \mathrm{~mm} \text { Thickness } \\
95 \% \text { Reflectivity }\end{array}$ & $15 \mathrm{USD} / \mathrm{pc}$ \\
\hline 3. Working Fluid & HFC-245fa & Honeywell & $\begin{array}{l}\text { b.p. } 15.3 \text { c.p. } 154^{\circ} \mathrm{C} \text { GWP } 950 \text {, } \\
\text { ODP } 0 \text {, nonflammable }\end{array}$ & $33 \mathrm{USD} / \mathrm{kg}$ \\
\hline 4. WF pump & Plunger & Hypro, Various & Common pressure washer pump & $300 \mathrm{USD} / \mathrm{pc}$ \\
\hline $\begin{array}{l}\text { 5. Heat transfer } \\
\text { fluid }\end{array}$ & Propylene Glycol & Various & $\begin{array}{l}\text { b.p. } 186^{\circ} \mathrm{C} \text {; used as antifreeze, } \\
\text { non-toxic }\end{array}$ & $3.50 \mathrm{USD} /$ litre \\
\hline 6. HTF Pump & $\begin{array}{l}\text { V-20 Power } \\
\text { Steering }\end{array}$ & Vickers & $\begin{array}{l}\text { Long haul truck power steering } \\
\text { pump }\end{array}$ & $290 \mathrm{USD} / \mathrm{pc}$ \\
\hline $\begin{array}{l}\text { 7. Fluid/tracking } \\
\text { motors }\end{array}$ & $24 \mathrm{VDC}$ & Leeson, Various & $\begin{array}{l}\text { High efficiency permanent } \\
\text { magnet drive }\end{array}$ & $300 \mathrm{USD} / \mathrm{pc}$ \\
\hline $\begin{array}{l}\text { 8. Expander - } \\
\text { generator }\end{array}$ & $\begin{array}{l}\text { Hermetic Scroll - } \\
\text { Induction machine }\end{array}$ & Copeland & Commercial HVAC compressor & $1000 \mathrm{USD} / \mathrm{pc}$ \\
\hline 9. Heat exchangers & $\begin{array}{l}\text { Brazed Plate } \\
\text { BP-410-30 }\end{array}$ & $\begin{array}{l}\text { ITT Brazepak, } \\
\text { Various }\end{array}$ & $\begin{array}{l}\text { Compact high efficiency heat } \\
\text { exchanger }\end{array}$ & $\begin{array}{l}500 \mathrm{USD} / \mathrm{pc} \\
40 \mathrm{USD} / \mathrm{kW}\end{array}$ \\
\hline 10. Air Condenser & $\begin{array}{l}\text { Force convection } \\
\text { finned copper tube }\end{array}$ & Carrier, Various & $\begin{array}{l}\text { Standard HVAC coils } 3 \text { rows } 3 / 8 \\
\text { ths tubing }\end{array}$ & $\begin{array}{l}45 \mathrm{USD} / \mathrm{kW} \\
\text { rejection }\end{array}$ \\
\hline $\begin{array}{l}\text { 11. Sensor based } \\
\text { Control system }\end{array}$ & $\begin{array}{l}\text { Microcontroller } \\
\text { and feedback } \\
\text { loops }\end{array}$ & $\mathrm{MIT} / \mathrm{STG}$ & Solar ORC system optimization & 1200 USD \\
\hline
\end{tabular}

* Note: Costs and specifications are based on data gathered in 2006 - 2009. They are subject to change, and generally do not represent official claims of the manufacturer.

As stated in section 1.4, the cost is a crucial parameter for the competitiveness of the technology. Several strategies and trade-offs are proposed to reduce to cost of the installed generation capacity:

- An electronic control unit is added for autonomous operation as sub-megawatt scale plants cannot justify the staffing of operating personnel.

- Operating at lower cycle temperatures $\left(<200{ }^{\circ} \mathrm{C}\right)$ and lower Carnot efficiency is another example of a design trade-off for maintaining low cost at small scales. For a given level of output power, lower temperatures enable cost savings in the materials and manufacture of the absorber units, heat exchangers, fluid manifolds and parabolic troughs. While the thermodynamic efficiency of heat engines increases with operating temperature, solar absorbers will have greater thermal losses due to convection and radiation [28]. Mitigating these losses under high-temperature operation, e.g. by means of selective high absorptivity and low emissivity coatings and evacuated glass glazing, entails higher costs in materials and manufacturing. These features may be economically justified in megawatt-scale installations, where large collector production volumes lead to lower specific costs and where the cost of 
land lease is an important consideration. Where the cost of space is not a constraint, however, and where small capacity units of deployment are preferred, optimization for the lowest LEC may lead to medium temperature designs involving lower thermal efficiencies and increased footprint, e.g. from $\sim 20 \mathrm{~m}^{2} / \mathrm{kWe}$ in a typical large scale Concentrating Solar Power (CSP) plant [29] to $\sim 35 \mathrm{~m}^{2} / \mathrm{kWe}$ in a medium temperature CSP plant.

- The use of widely available components (mainly from the HVAC) market allows economies of scale compared to components that would be specially designed for ORC units.

The cost of the system was evaluated by the authors in a previous work [29]. Since commercial cost or performance data is not yet available for such a system, a thermodynamic model of each subcomponent has been built and validated. The different component models have then been interconnected to evaluate the performance of the system. An overall efficiency (solar to electricity) of $8 \%$ was predicted, with conservative hypotheses [30]. A cost model of each component (Table 2) has then been implemented to evaluate the LEC of each $\mathrm{kWh}$ produced by the system.

Preliminary results indicate specific costs (a 15 year Levelized Cost of Electricity) for the $3 \mathrm{kWe}$ reference system of approximately $\$ 0.25 / \mathrm{kWh}$, which compares favourably with $\mathrm{PV}$ systems $(>\$ 0.30 / \mathrm{kWh})$ and diesel generation $(>\$ 0.50 / \mathrm{kWh})$ in installed in off-grid areas [29].

Decentralized power generation is justified in much of Lesotho: the density of population is low (around 60 persons per $\mathrm{km}^{2}$, much lower in rural areas), most of the areas are mountainous, and the current grid only covers a small portion (around 15\%) of the territory (Figure 4).

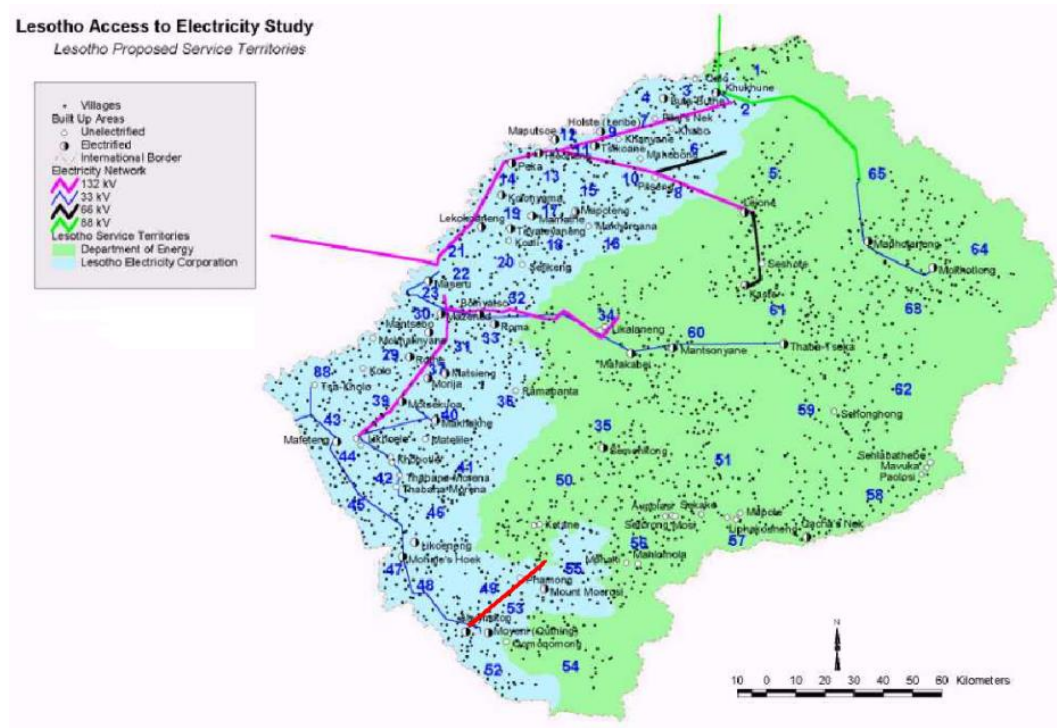

Figure 4. Map of the electric grid in Lesotho (Source: [31])

Technology transfer and training is an important part of the project concept. Local technicians and engineers have been hired and trained in theoretical and practical aspects of assembly of a micro-CSP system with ORC. In 2011 the locally trained team built their first complete plant (Matjotjo Pilot), which is an important competency to facilitate maintenance and foster the replication of the power plant. It should be noted that at present Lesotho lacks indigenous engineering infrastructure in the industrial and workforce development sectors, which is problematic for production and maintenance activities. To begin to address this, 
STG International has equipped workshops with suitable machining tools (mills, lathes, welding machines, etc.) in conjunction with training in manufacturing processes.

The proposed approach aims to complement traditional methods of rural electrification and address the challenging aspects of extending sustainable energy supplies in developing countries. As a cogeneration technology, micro-CSP is more flexible than PV or fossil-fuel based equipment in meeting variable (thermal and electrical) demand loads, and is scalable and repairable onsite. Since it is a nascent technology, strategies are needed to increase awareness of micro-CSP, foster capacity for its production and deployment, and establish supply chains and validated business models for service provision, including financing mechanisms and institutional arrangements. These tasks are substantial, and necessarily start with a demonstration phase, to which end prototype and pilot micro-CSP plants have been installed in community and health clinic settings to elicit user feedback and progress down the technical learning curve.

The selection of new technologies or distribution models is inherently risky: because micro-CSP is new, its proven reliability over time is less established than the PV or diesel technologies that have been deployed in the field for decades. Reliability issues could reduce the potential of technology adoption by local communities, if the proposed systems work intermittently, experience regular failures, or otherwise fail to meet expectations (which is likely in an initial pilot). It is important therefore to differentiate the prototyping and demonstration phases, where experimental installations are invaluable tools for testing innovation, from a diffusion phase which must meet customer demands and economic criteria. The diffusion phase can only take place when minimum system reliability and cost effectiveness is reached, preferably following the results of a validation study with comparison groups of unelectrified sites and sites employing traditional electrification approaches. The authors propose that this activity, a comparative cost analysis of micro-utility technologies and models, should be the subject of further research efforts to establish best practices in the field of sustainable energy approaches for rural development.

\section{CONCLUSIONS}

At present more than 1.4 billion people worldwide lack access to electricity [1]. Many communities will continue to lack access to centralized grid infrastructure due to remoteness or low rates of return on investment in grid extension. Small scale, decentralized concentrating solar power can constitute a cost effective energy solution for remote places with a high solar direct normal irradiation.

In this work, experience relative to a number of implemented rural electrification projects has been synthesized to generate a set of best practices or guiding principles for innovating within energy service provision projects. While some divergence of thought occurs when considering principles such as market deployment or subsidies, there is general agreement amongst sources regarding appropriate approaches, and these are summarized with reference to a proposed micro-utility project concept involving micro-CSP technology.

This project in turn has been planned to the extent possible to conform to the formulated recommendations: locally available materials and components are privileged; design trade-offs have been calibrated to obtain a competitive specific cost of energy; training programs for local technicians have been established; and local inquiries to establish demand have been performed.

At the present time, experimental data is lacking for the installed micro-CSP plants or proposed distribution models. Initial experimental results on individual component tests are promising: a collector efficiency of about $60 \%$ was achieved, and the first tests on the scroll expanders showed that an overall isentropic efficiency over $70 \%$ can be obtained. 
Extrapolating from these experimental results, it was shown through thermodynamic simulation that an overall system efficiency of $8 \%$ is achievable. This efficiency is lower than that of PV systems, but it is justified by a lower project cost and by the cogeneration of thermal products.

Additional research is necessary to establish performance benchmarks and cost functions of micro-CSP and competing technologies in micro-utility deployments in off grid areas. A longitudinal comparative analysis is recommended using control groups at similar deployments, such as health clinics or education facilities, to establish relevant cost, reliability and operating and maintenance metrics.

\section{REFERENCES}

1. World Bank, World Databank, http://databank.worldbank.org/data/views/variableSelection/selectvariables.aspx?sour ce=world-development-indicators, [Accessed: 15-Dec-2012] World Development Indicators

2. World Bank. (1996). Rural energy and development: improving energy supplies for two billion people. Washington, D.C., World Bank.

3. Benka, S. (2002) "The Energy Challenge", Physics Today (55:38), April, http://dx.doi.org/10.1063/1.1480780

4. The World Bank, (2008) The Welfare Impact of Rural Electrification: A Reassessment of the Costs and Benefits. IEG Impact Evaluation 45400, Washington, DC.

5. Hiremath, R.B., Shikha, S. and Ravindranath, N.H., (2007) "Decentralized energy planning; modeling and application - a review" Renewable and Sustainable Energy Reviews, 11, pp.729-752, http://dx.doi.org/10.1016/j.rser.2005.07.005

6. Energy for Sustainable Development, (2003) Study on PV Market Chains in East Africa. World Bank, Washington DC. October

7. Barnes, D. F. (2007). The challenge of rural electrification: strategies for developing countries. Washington, DC, Resources for the Future: Energy Sector Management Assistance Program.

8. Zilles, R., Lorenzo, E., et al. (2000). "From candles to PV electricity: A four-year experience at Iguape-Cananeia, Brazil." Progress in Photovoltaics 8(4): 421-434, http://dx.doi.org/10.1002/1099-159X(200007/08)8:4<421::AID-PIP323>3.0.CO;2-J

9. Martinot, E., Chaurey, A., et al. (2002). "Renewable energy markets in developing countries." Annual Review of Energy and the Environment 27: 309-348, http://dx.doi.org/10.1146/annurev.energy.27.122001.083444

10. Cernea, M. M. and World Bank. (1991). Putting people first: sociological variables in rural development. New York, Oxford University Press.

11. Akrich M. (1987). "Comment les innovations réussissent?", Recherche et Technologie 4: 26-34

12. Nieuwenhout, F. D. J., van Dijk, A., et al. (2001). "Experience with solar home systems in developing countries: A review." Progress in Photovoltaics 9(6): 455-474, http://dx.doi.org/10.1002/pip.392

13. Schumacher, E. F. (1973). Small is beautiful; economics as if people mattered. New York, Harper \& Row.

14. Miller, D. and Hope, C. (2000). "Learning to lend for off-grid solar power: policy lessons from World Bank loans to India, Indonesia, and Sri Lanka." Energy Policy 28(2): 87-105, http://dx.doi.org/10.1016/S0301-4215(99)00071-3

15. Chaurey A., K. T. (2010). "A techno-economic comparison of rural electrification based on solar home systems and PV microgrids." Energy Policy, http://dx.doi.org/10.1016/j.enpol.2010.01.052 
16. Santos Pérez, F. J., Linares Llamas, P., Metodología de ayuda a la decisiónpara la electrificación rural apropiada en países en vías de desarrollo, Madrid, 2003

17. Kammen, D. M. and Kirubi, C. (2008). "Poverty, energy, and resource use in developing countries - Focus on Africa." Reducing the Impact of Poverty on Health and Human Development: Scientific Approaches 1136: 348-357.

18. Kirubi, C., Jacobson, A., et al. (2009). "Community-Based Electric Micro-Grids Can Contribute to Rural Development: Evidence from Kenya." World Development 37(7): 1208-1221, http://dx.doi.org/10.1016/j.worlddev.2008.11.005

19. Chakrabarti, S. and Chakrabarti, S. (2002). "Rural electrification programme with solar energy in remote region - a case study in an island." Energy Policy 30(1): 33-42., http://dx.doi.org/10.1016/S0301-4215(01)00057-X

20. Zomers, A.N. (2001). Rural Electrification: Utilities' Chafe or Challenge, Twente University Press, Enschede, Pays-Bas

21. Freris, L. L. and Infield, D. G. (2008). Renewable energy in power systems. Chichester, U.K., John Wiley \& Sons.

22. Karani, P. (2002). "Technology transfer to Africa: Constraints for CDM operations." Refocus 3(3): 20-23, http://dx.doi.org/10.1016/S1471-0846(02)80037-3

23. FulfordDJ., M. P., Gill A. (2000). "Recommendations on the use of micro-hydro power in rural development." Journal of International Development 12: 975-983., http://dx.doi.org/10.1002/1099-1328(200010)12:7<975::AID-JID699>3.0.CO;2-K

24. Wamukonya, N. (2007). "Solar home system electrification as a viable technology option for Africa's development." Energy Policy 35(1): 6-14, http://dx.doi.org/10.1016/j.enpol.2005.08.019

25. Lorenzo, E. (1997). "Photovoltaic rural electrification." Progress in Photovoltaics 5(1): 3-27, http://dx.doi.org/10.1002/(SICI)1099-159X(199701/02)5:1<3: :AID-PIP158>3.0.CO;2-H

26. Morris, E., Chowdhary S. (2009) Las Microfinanzas en la ExpansióndelAcceso a los Servicios de Energía. Resumen de Conclusiones, CITI Fundcation\& USAID, Mexico

27. Lemort V., Declaye S., Quoilin S. (2008). " Experimental characterization of a hermetic scroll expander for use in a micro-scale Rankine cycle" Proceedings of the Institution of Mechanical Engineers, Part A: Journal of Power and Energy 226-1, pp 126-136

28. Forristall, R.. (2003) Heat Transfer Analysis and Modeling of a Parabolic Trough Solar Receiver Implemented in Engineering Equation Solver. Technical Report October, National Renewable Energy Laboratory, Golden, CO, http://dx.doi.org/10.2172/15004820

29. Orosz, M., Quoilin, S., and Hemond, H. (2010). SORCE: A design tool for solar organic Rankine cycle systems in distributed generation applications, Eurosun 2010.

30. Quoilin, S., Orosz, M., and Lemort, V. (2011). Performance and Design optimization of a low-cost solar organic Rankine cycle for remote power generation. Solar Energy, Volume 85, Issue 5, May 2011, pp.955-966, http://dx.doi.org/10.1016/j.solener.2011.02.010

31. Global Energy Network Institute, Lesotho Access to Electricity Study, http://www.geni.org/globalenergy/library/national_energy_grid/lesotho/lesothonation alelectricitygrid.shtml, [Accessed: 02-March-2013], 2011 